\title{
EXPERIMENTAL STUDY OF ANTIMICROBIAL PROPERTIES AND ACUTE TOXICITY OF THE PEO-BASED COMBINED SUPPOSITORIES
}

\author{
Tymur Ravshanov \\ Department of clinical pharmacology IPPQI \\ b2ja89@gmail.com \\ Ganna Zaychenko \\ Department of pharmacology $y^{l}$ \\ Bogomolets National Medical University \\ 13 Shevchenko blvd., Kyiv, Ukraine, 01601 \\ anna.zajjchenko@gmail.com \\ Kateryna Zhemerova \\ Laboratory of Pharmacopoeia Analysis \\ SE "Ukrainian Scientific Pharmacopoeia Center for the Quality of Medicines" \\ 33 Astromonichna str., Kharkiv, Ukraine, 61085 \\ Volodymyr Zaychenko \\ Department of industrial technology of drugs ${ }^{1}$ \\ National University of Pharmacy \\ Olena Ruban \\ Department of industrial technology of drugs ${ }^{1}$ \\ ${ }^{1}$ National University of Pharmacy \\ 53 Pushkinska str., Kharkiv, Ukraine, 61002
}

\begin{abstract}
Aim. The research of antimicrobial and toxicological parameters of a promising pharmaceutical composition with indole-3-carbinol and meloxicam in the form of rectal suppositories.

Materials and methods. The research of antimicrobial activity was carried out in vitro by diffusion in nutrient agar in the modification of "holes" on the reference strains of common pathogens Staphylococcus aureus, Pseudomonas aeruginosa, Escherichia coli, Bacillus subtilis, Candida albicans.

Adult rats were used for the study of acute toxicity. Suppository mass were administrated in the largest possible volume rectally or orally. The animals were periodically monitored according to the experimental plan - the assessment of physiological parameters before administration and after $6,12,18,24$ hours, at 3, 7 and 14 days. The animals were removed from experiment and necropsy provided after $1,3,7$, and 14 days.

Results. The sizes of zones of inhibition of the microorganisms growth were most significant (from $19.27 \pm 0.61 \mathrm{~mm}$ of E. coli to $40.80 \pm 0.42 \mathrm{~mm}$ of S. aureus) near sample of the combined composition suppository compared with other combination of active substances and excipients.

During the observation of animals for 14 days and the study of internal organs after autopsy, deviations in physiological (weight, temperature, activity, respiratory rate) and macroscopic morphological indicators of animals from reference values were not detected.

Conclusion. According to the results of microbiological studies, a moderate antimicrobial effect of suppositories of combined composition in relation to all the studied pathogens was revealed. The absence of manifestations of acute toxicity allows us to conclude that the pharmaceutical composition can be classified as practically non-toxic substances.

The obtained results allow us to recommend a pharmaceutical composition with indole-3-carbinol and meloxicam on a polyethylene oxide basis in the form of suppositories for further preclinical studies of specific pharmacological effects as a prostate protective agent.
\end{abstract}

Keywords: indole-3-carbinol, meloxicam, antimicrobial activity, acute toxicity. 


\section{Introduction}

The metabolite of plant glucosinolates indole-3-carbinol (I3C) is a promising treatment for prostate diseases [1]. The effectiveness of I3C as a component of complex therapy of hormone-dependent diseases of benign prostatic hyperplasia (BPH), prostate carcinoma, uterine fibroids, fibrocystic mastopathy is confirmed. Experimentally demonstrated high antitumor activity of I3C and its metabolite DIM with respect to prostate cancer [2], the ability to induce cell apoptosis, inhibit the growth of androgen-dependent and androgen-independent cell cultures of this gland [3]. As well as the ability to block the proliferation of signals (in particular, the activation of nuclear transcription factor NF-kB and protein kinase Akt [4]) in prostate cells by inhibiting the expression of androgen receptors, which play an important role in the pathogenesis of $\mathrm{BPH}$ [5]. I3C exerts a modulating effect on estrogen receptors (ER) and the number of androgen receptors (AR) [6] Based on its pharmacodynamic characteristics, it can be assumed that I3C may have a complex effect on the mechanisms of BPH and CP.

Useful for the treatment of prostatitis is the antimicrobial activity of $\mathrm{I} 3 \mathrm{C}$, as there are reports that the substance exhibits broad-spectrum antibacterial activity, in particular, in Candida albicans, I3C stops the cell cycle in phase $\mathrm{G}(2) / \mathrm{M}$, thus destroying the structure of the cell membrane of C. albicans [7].

Diseases of the gland are also characterized by an increase in the activity of cytokines, growth factors, cyclooxygenase (COX) type 1 and 2, inducers of angiogenic, anti-apoptotic and inflammatory processes. It is believed that the inhibition of inflammation may reduce the risk of prostate disease. It is therefore important that $\mathrm{I} 3 \mathrm{C}$ exhibits antimicrobial, anti-inflammatory, antioxidant properties.

Non-steroidal anti-inflammatory drugs (NSAIDs) have a more specific anti-inflammatory effect. They are widely used in the world because of their antinociceptive, anti-inflammatory effects, particularly in cancer and other prostate diseases, although there is still no consensus on the usefulness of NSAIDs in prostate diseases, but they believe this to be the case for treating BPH and prostate cancer [8]. With the use of NSAIDs, COX-1 and COX-2 inhibitors reduce the symptoms of inflammation and improve the quality of life of patients with chronic prostatitis [9], reduce the risk of BPH development and progression [10]. In clinical studies, it has been shown that, with the use of NSAIDs, a greater reduction in the average international prostate symptom score and faster relief of BPH symptoms have been observed [11], thought to be due to a decrease in viability and inhibition of BPH cell line proliferation [12].

A combination of $\mathrm{I} 3 \mathrm{C}$ and a non-steroidal anti-inflammatory drug is considered to be appropriate to increase the efficacy of the drug and expand the range of pharmacological effects and indications for use. Meloxicam is a selective cyclooxygenase type 2 inhibitor with pronounced anti-inflammatory properties due to inhibition of arachidonic acid metabolism. He is thought to be at lower risk of damage to the gastric mucosa [13], although there is a risk of cardiovascular events, especially with prolonged treatment [14].

That is why, when designing new highly effective drugs, the dosage form is important, which provides optimal therapeutic effect with minimal side effects. The use of rectal suppositories as the optimal dosage form is relevant for the problem of prostate treatment [15]. They have several advantages over other dosage forms: independence of the completeness of absorption from the functional state of the gastrointestinal tract; the maximum part of the dose of the drug bypasses the processes of presystemic metabolism and invariably enters the prostate; high absorption rate (comparable to parenteral routes of administration), in most cases no allergic effect on the body; independence of the input path from the state of other systems; ease of use; metering accuracy. This is confirmed by studies of local reaction, safety and efficacy of meloxicam suppositories (15 mg) over 3 weeks, which showed no significant adverse events, and approximately $90 \%$ of people rated meloxicam response and treatment efficacy as good or very good [16].

During the research, the authors proposed the optimal composition of a promising pharmaceutical composition for the treatment of prostate diseases in the form of rectal suppositories with I3C and meloxicam. To compare the efficacy of the release of the active substances from the two variants of the suppository base (solid fat and polyethylene oxide (PEO)), a screening study was performed on a 
model of turpentine prostatitis [17]. The availability of the active components was determined by the degree of inhibition of inflammation and the effect on the hormonal background of the animals. Because PEO-based suppositories had a more pronounced effect on the course of the inflammatory process and reduced serum testosterone content, they were selected as a promising drug for further in-depth pharmacological research including the determination of acute toxicity and antimicrobial activity.

Aim of the research. Microbiological and toxicological study of a new preparation in the form of rectal polyethylene oxide-based suppositories (SCS-PEO) containing indole-3-carbinol and meloxicam.

\section{Materials and methods}

In the study of the antimicrobial properties of SCS-PEO, as the substances were used meloxicam (BoehringerIngelheimGmbH, Germany) and I3C (Sigma-Aldrich Co., USA), as well as samples of some variants of suppositories of the following composition:

- Sample 1 - PEO-base: a mixture of PEO-1500 and PEO-400 (95:5); Montanox 80 (Polysorbate-80);

- Sample 2 - PEO basis; Montanox 80; indole-3-carbinol (0.2 g/suppository);

- Sample 3 - PEO basis; Montanox 80; meloxicam (0.0075 g/suppository);

- Sample 4 - SCS-PEO;

- Sample 5 - PEO basis; indole-3-carbinol (0.2 g/suppository);

- Sample 6 - PEO basis; indole-3-carbinol (0.2 g/suppository); meloxicam (0.0075 g/1 suppository)

Microbiological study was performed on clinically significant pathogens of inflammatory diseases of the genitourinary system (including prostatitis). The reference strains of bacteria and fungi were taken from the Ukrainian Collection of Microorganisms of the Institute of Microbiology and Virology named after I. V. Zabolotnyi (Kyiv, Ukraine): Staphylococcus aureus (ATCC 6538), Pseudomonas aeruginosa (ATCC 9027), Escherichia coli (ATCC 8739), Bacillus subtilis (ATCC 6633), Candida albicans (ATCC 10231).

The bacterial test strains were cultured at about $35{ }^{\circ} \mathrm{C}$ for 18 to 24 hours. on soybean casein agar. The studied C. albicans microorganism was grown on Saburo dextrose agar at a temperature of about $35{ }^{\circ} \mathrm{C}$ for 24 to 48 hours.

Before starting the experiment, the purity of each culture and its typical properties were checked for morphological, cultural and staining (for bacteria) characteristics.

A standard pharmacopoeial turbidity sample (PSS SPU) of 10 IU was used to prepare a microbial suspension of standard concentration [19-21].

Studies on the specific antimicrobial action of the drug were performed in vitro by diffusion into nutrient agar with the modification of the wells in accordance with the recommendations [22-25].

Acute toxicity studies were performed with single administration of the maximum possible amount of the drug, since known maximum toxic doses for the active substances could not be achieved.

All experiments were carried out in accordance with the Law of Ukraine "On the Protection of Animals against Cruelty", which was agreed with the European Convention on the Protection of Vertebrate Animals of 1986 [26, 27]. Experiments were approved by the Bioethics Commission of the National University of Pharmacy (excerpt from protocol No. 3 of 20.04.2016).

Acute toxicity studies were conducted on 32 adult male rats randomized to 2 subgroups for oral and rectal administration of the study agent. Rats from subgroup 1 were injected intragastrically with a single dose of $4.5 \mathrm{~g}$ of SCS-PEO suppository, which corresponded to the administration of $10.75 \mathrm{mg}$ meloxicam and $300 \mathrm{mg}$ I3C per animal. Rats of subgroup 2, using a soft probe, performed rectal administration of the drug at a dose of $1 \mathrm{~g}$, which corresponded to the administration of $2.5 \mathrm{mg}$ meloxicam and $67.7 \mathrm{mg}$ I3C per animal [18].

Over the next 24 hours, the animals were continuously monitored for physiological parameters. From 1 to 14 days we carried out daily assessment of the animals. The animals were removed according to the scheme - 4 animals from both subgroups after 1, 3, 7 and 14 days after the introduction of the studied SCS-PEO by rapid decapitation. 
Physiological (measurement of basal body temperature, respiratory rate, monitoring of activity, feed and water consumption) and morphological parameters (body and organ weight, macroscopic morphological evaluation of internal organs) were used to evaluate toxicodynamics [28].

Statistical processing of the results was carried out using software using variation statistics methods using parametric and non-parametric methods of analysis (Student and Mann-Whitney criteria) and presented as comparative tables with the results of different groups as arithmetic mean and its error $(\mathrm{M} \pm \mathrm{m})$ or Median and 25 and 75 percentile (Me, LQ; UQ). Differences were considered statistically significant at $\mathrm{p}<0.05$ [29].

\section{Results}

The results of a comparative study of the antimicrobial activity of suppository samples by agar diffusion (Table 1) against reference strains of bacteria and fungi showed that Sample 1, which includes Montanox 80 and PEO-base, has no antimicrobial effect against $B$. subtilis (ATCC 6633), P. aeruginosa (ATCC 9027), S. aureus (ATCC 6538) and C. albicans (ATCC 10231). Small areas of inhibition of growth of $E$. coli (ATCC 8739) with a diameter of $13.27 \pm 0.36 \mathrm{~mm}$ were observed, indicating little antimicrobial activity against this bacterium.

Despite the absence of a well-described mechanism of antimicrobial activity, suppositories of I3C (Sample 2) showed antimicrobial action against all tested microorganisms used as reference. The most pronounced activity was observed for $S$. aureus - the area of inhibition of growth of $S$. aureus (ATCC 6538) was $38.60 \pm 0.99 \mathrm{~mm}$, i. e., indicates a high level of antibacterial activity. High antibacterial activity was also observed in relation to gram-positive B. subtilis (ATCC 6633) - the diameter of the growth inhibition zone was $27.83 \pm 0.77 \mathrm{~mm}$. Gram-negative bacteria showed moderate sensitivity to Sample 2, the diameter of the zone of inhibition of growth of E. coli and purulent sticks was less than $20 \mathrm{~mm}$ (Table 1). Concerning the strain of the yeast fungus C. albicans (ATCC 10231), Sample 2 showed a moderate antifungal effect - the diameter of the growth inhibition zone was $22.43 \pm 0.33 \mathrm{~mm}$.

The severity of antibacterial and antifungal action of suppositories with I3C was not significantly dependent on the presence (Sample 5) or absence (Sample 2) of Montanox 80. The diameter of the growth inhibition zones of each of the studied organisms B. subtilis (ATCC 6633), E. coli (ATCC 8739), P. aeruginosa (ATCC 9027), S. aureus (ATCC 6538), and C. albicans (ATCC 10231) for Sample 5 did not differ significantly from the values obtained for Sample 2 (Table 1).

Suppositories with meloxicam (Sample 3) did not show antimicrobial activity against the microorganisms B. subtilis (ATCC 6633), P. aeruginosa (ATCC 9027), S. aureus (ATCC 6538) and C. albicans (ATCC 10231) - no growth inhibition zones were present. About E. coli (ATSC 8739) had poorly expressed activity - the diameter of the growth inhibition zone was significantly smaller than the diameter of the growth zones of E. coli for Sample 1.

Table 1

Antimicrobial activity of tested samples of suppositories

\begin{tabular}{|c|c|c|c|c|c|c|}
\hline \multirow{2}{*}{$\begin{array}{c}\text { The studied } \\
\text { microorganisms }\end{array}$} & \multicolumn{6}{|c|}{ Growth inhibition zone diameter, $\mathrm{mm}(\mathrm{M} \pm \mathrm{m}, \mathrm{n}=6)$} \\
\hline & Sample 1 & Sample 2 & Sample 3 & Sample 4 & Sample 5 & Sample 6 \\
\hline $\begin{array}{c}\text { B. subtilis } \\
\text { (ATCC 6633) }\end{array}$ & No zone & $27.83 \pm 0.77$ & No zone & $29.96 \pm 0.69$ & $25.38 \pm 1.20$ & $29.22 \pm 0.51^{\text {c) }}$ \\
\hline $\begin{array}{c}\text { E. coli } \\
\text { (ATCC 8739) }\end{array}$ & $13.27 \pm 0.36$ & $18.52 \pm 0.26$ & $11.68 \pm 0.39^{\text {a) }}$ & $19.27 \pm 0.61$ & $18.50 \pm 0.21$ & $18.38 \pm 0.33$ \\
\hline $\begin{array}{l}\text { P. aeruginosa } \\
\text { (ATCC 9027) }\end{array}$ & No zone & $16.35 \pm 0.43$ & No zone & $17.75 \pm 0.34^{b)}$ & $16.87 \pm 0.45$ & $17.65 \pm \cdot .31$ \\
\hline $\begin{array}{c}\text { S. aureus } \\
\text { (ATCC 6538) }\end{array}$ & No zone & $38.60 \pm 0.99$ & No zone & $40.80 \pm 0.42$ & $37.43 \pm 0.78$ & $39.53 \pm 0.53$ \\
\hline $\begin{array}{c}\text { C. albicans } \\
\text { (ATCC 10231) }\end{array}$ & No zone & $22.43 \pm 0.33$ & No zone & $20.27 \pm 0.48^{b)}$ & $22.43 \pm 0.57$ & $19.95 \pm 0.26^{\mathrm{c}}$ \\
\hline
\end{tabular}

Note: ${ }^{a)}$ - a significant difference $(p<0.05)$ compared to the results of Sample $1 ;{ }^{b}$ - a significant difference $(p<0.05)$ compared to the results of Sample 2; ${ }^{c}$ - a significant difference $(p<0.05)$ compared to the results of Sample 5 
The antimicrobial activity of samples of suppositories containing I3C and meloxicam did not differ significantly from the activity of suppositories containing only I3C. It should be noted that there was a certain tendency to increase the degree of antibacterial activity in the presence of meloxicam in suppositories, but the difference in the diameters of growth inhibition zones was only significant in two cases - for Samples 2 and 4 for P. aeruginosa (ATCC 9027) and for Samples 5 and 6 regarding $B$. subtilis (ATCC 6633). In contrast, the antifungal activity of suppositories containing I3C and meloxicam against $C$. albicans (ATCC 10231) was significantly lower than that of suppositories containing I3C only.

After a single intragastric or rectal administration of the suppository mass of SCS-PEO, the animals remained alive on the first day and had normal appearance and behavior. In the future, at all times of observation, mobility, condition of the hair, open areas of the skin, eating behavior, excretion did not differ from the usual for laboratory rats. There were no unusual movements, tremors, and more. Body weight did not change statistically significantly over 14 days.

The results of the study of toxicodynamics by physiological (basal temperature, respiratory rate, observation of activity, feed and water consumption) and morphological (mass and macroscopic morphological evaluation of internal organs, determination of body weight and its changes) indicators in rats, which were once administered with suppository SCS-PEO shown in Fig. 1. The data obtained during the first observation day every $6 \mathrm{~h}$ and in the following observation periods are presented: 3,7 and 14 days.
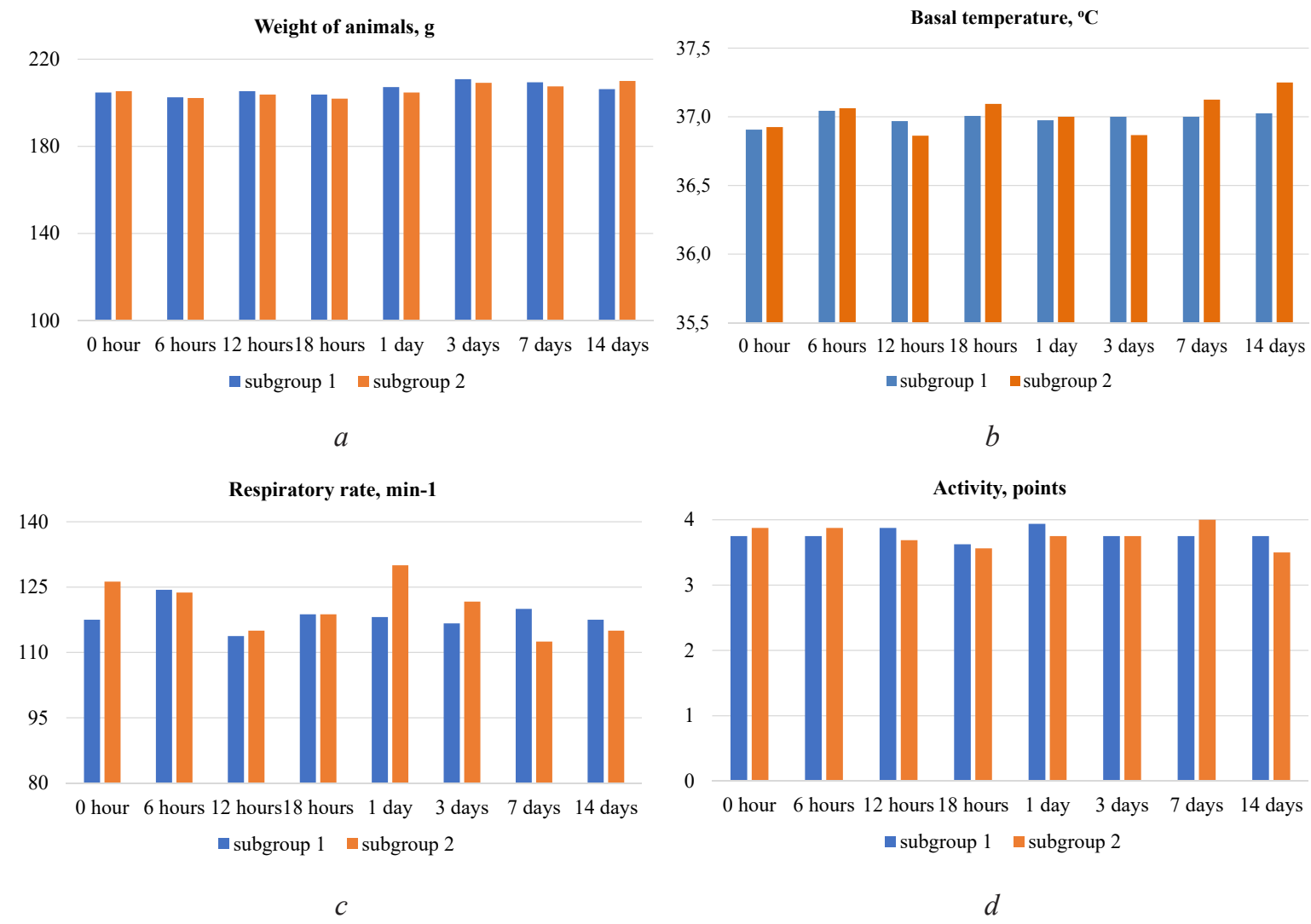

Fig. 1. Physiological indices of rats receiving suppository mass of SCS-PEO: subgroup 1 - oral administration; subgroup 2 - rectal administration. For $0,6,12,18,24$ hours: $n=16 ; 3$ days: $n=12$; 7 days: $\mathrm{n}=8 ; \mathrm{n}=4 ; a$ - animal body weight; $b$ - basal temperature; $c$ - respiratory rate; $d$ - activity

At the necropsy of animals at day 14, it was noted that the hair of the animals was soft and shiny, the natural ostium (eyes, mouth, ears, anus and penis) were dry, without secretions, the mucous membranes were shiny, pale pink. 
The location, size, density, and colour of the thymus, heart, lungs, liver, spleen, kidneys, prostate, testes, and vesicles did not differ from these control animals. As shown in Table 2, in all observation periods the mass coefficients of the organs have no significant differences with the reference indicators and in rats of both groups (oral and rectal administration) remained within the reference age norm [30].

Macroscopic morphological examination revealed that $25 \%$ of subgroups 1 (oral administration) rats withdrawn from the experiment at $24 \mathrm{~h}$ and 3 days showed gastric mucosa. This may be related to the effect of meloxicam, since inhibition of cyclooxygenase activity may slightly reduce the antacid protection of the gastric mucosa [31].

It should be noted that the calculated therapeutic dose of the SCS-PEO suppository for meloxicam is $0.45 \mathrm{mg} / \mathrm{kg}$, which, respectively, for rats weighing 200-220 g is a dose of 0.09$0.10 \mathrm{mg} / \mathrm{kg}$. In our study, rats in subgroup 1 received oral meloxicam at a dose of $10.45 \mathrm{mg}$. Considering that the therapeutic dosage of the study drug was exceeded more than 100 times, the mucous membrane hyperaemia can be considered as an expected undesirable manifestation.

Table 2

Mass ratios of organs of rats receiving suppository mass of SCS-PEO orally (subgroup 1) or rectally (subgroup 2) $\left(1 \cdot 10^{-3}, \mathrm{n}=4, \mathrm{Me}, \mathrm{LQ}\right.$; UQ)

\begin{tabular}{|c|c|c|c|c|}
\hline Reference rate [12] & 24 hours & 3 days & 7 days & 14 days \\
\hline 1 & 2 & 3 & 4 & 5 \\
\hline \multirow{4}{*}{$\begin{array}{c}\text { Heart } \\
4.2 \\
(3.8 ; 4.6)\end{array}$} & \multicolumn{4}{|c|}{ Subgroup 1 (oral administration) } \\
\hline & $4.44(4.37 ; 4.48)$ & $4.32(4.29 ; 4.33)$ & $4.28(4.26 ; 4.31)$ & $4.43(4.41 ; 4.47)$ \\
\hline & \multicolumn{4}{|c|}{ Subgroup 2 (rectal administration) } \\
\hline & $4.35(4.23 ; 4.46)$ & $4.46(4.38 ; 4.50)$ & $4.25(4.24 ; 4.26)$ & $4.49(4.42 ; 4.53)$ \\
\hline \multirow{4}{*}{$\begin{array}{c}\text { Lungs } \\
17.6 \\
(15.6 ; 18.6)\end{array}$} & \multicolumn{4}{|c|}{ Subgroup 1 (oral administration) } \\
\hline & $16.50(16.27 ; 16.62)$ & $16.71(16.31 ; 16.97)$ & $16.34(15.91 ; 16.81)$ & $16.30(16.11 ; 16.65)$ \\
\hline & \multicolumn{4}{|c|}{ Subgroup 2 (rectal administration) } \\
\hline & $16.85(16.47 ; 17.15)$ & $16.96(16.52 ; 17.22)$ & $16.69(16.28 ; 17.07)$ & $16.50(16.19 ; 16.77)$ \\
\hline \multirow{4}{*}{$\begin{array}{c}\text { Thymus } \\
2.2 \\
(2.1 ; 2.3)\end{array}$} & \multicolumn{4}{|c|}{ Subgroup 1 (oral administration) } \\
\hline & $2.17(2.14 ; 2.19)$ & $2.24(2.19 ; 2.24)$ & $2.20(2.17 ; 2.22)$ & $2.18(2.13 ; 2.19)$ \\
\hline & \multicolumn{4}{|c|}{ Subgroup 2 (rectal administration) } \\
\hline & $2.11(2.08 ; 2.15)$ & $2.21(2.13 ; 2.26)$ & $2.16(2.11 ; 2.21)$ & $2.13(2.11 ; 2.13)$ \\
\hline \multirow{4}{*}{$\begin{array}{c}\text { Liver } \\
51.80 \\
(50.4 ; 53.2)\end{array}$} & \multicolumn{4}{|c|}{ Subgroup 2 (rectal administration) } \\
\hline & $51.49(50.93 ; 52.03)$ & $51.67(50.56 ; 52.44)$ & $52.08(51.67 ; 52.43)$ & $51.97(51.16 ; 52.53)$ \\
\hline & \multicolumn{4}{|c|}{ Subgroup 2 (rectal administration) } \\
\hline & $52.42(51.17 ; 53.66)$ & $51.76(51.20 ; 52.52)$ & $50.53(50.26 ; 51.50)$ & $51.17(51.05 ; 51.34)$ \\
\hline \multirow{4}{*}{$\begin{array}{c}\text { Spleen } \\
6.2 \\
(5.8 ; 6.6)\end{array}$} & \multicolumn{4}{|c|}{ Subgroup 2 (rectal administration) } \\
\hline & $6.23(6.17 ; 6.28)$ & $5.94(5.92 ; 6.05)$ & $6.08(5.94 ; 6.20)$ & $6.15(6.06 ; 6.22)$ \\
\hline & \multicolumn{4}{|c|}{ Subgroup 2 (rectal administration) } \\
\hline & $6.00(5.95 ; 6.06)$ & $6.07(5.99 ; 6.11)$ & $6.06(6.01 ; 6.10)$ & $6.32(6.19 ; 6.35)$ \\
\hline \multirow{4}{*}{$\begin{array}{c}\text { Kidneys } \\
16.0 \\
(15.6 ; 16.4)\end{array}$} & \multicolumn{4}{|c|}{ Subgroup 1 (oral administration) } \\
\hline & $15.89(15.62 ; 16.15)$ & $15.87(15.57 ; 16.29)$ & $16.07(15.91 ; 16.16)$ & $16.07(15.71 ; 16.36)$ \\
\hline & \multicolumn{4}{|c|}{ Subgroup 2 (rectal administration) } \\
\hline & $16.58(16.14 ; 16.79)$ & $16.65(16.44 ; 16.71)$ & $15.64(15.63 ; 15.71)$ & $16.18(16.02 ; 16.24)$ \\
\hline
\end{tabular}




\begin{tabular}{|c|c|c|c|c|}
\hline 1 & 2 & 3 & 4 & 5 \\
\hline \multirow{4}{*}{$\begin{array}{c}\text { Prostate } \\
3.2 \\
(3.0 ; 3.4)\end{array}$} & \multicolumn{4}{|c|}{ Subgroup 1 (oral administration) } \\
\hline & $3.15(3.14 ; 3.18)$ & $3.18(3.07 ; 3.27)$ & $3.21(3.12 ; 3.26)$ & $3.09(3.07 ; 3.11)$ \\
\hline & \multicolumn{4}{|c|}{ Subgroup 2 (rectal administration) } \\
\hline & $3.19(3.09 ; 3.27)$ & $3.18(3.13 ; 3.22)$ & $3.11(3.10 ; 3.14)$ & $3.18(3.12 ; 3.23)$ \\
\hline \multirow{4}{*}{$\begin{array}{c}\text { Seminal vesicles } \\
5.1 \\
(5.0 ; 5.3)\end{array}$} & \multicolumn{4}{|c|}{ Subgroup 1 (oral administration) } \\
\hline & $5.05(4.99 ; 5.10)$ & $5.23(5.06 ; 5.33)$ & $5.21(5.14 ; 5.23)$ & $5.23(5.11 ; 5.28)$ \\
\hline & \multicolumn{4}{|c|}{ Subgroup 2 (rectal administration) } \\
\hline & $5.07(4.99 ; 5.18)$ & $5.25(5.15 ; 5.29)$ & $5.10(5.05 ; 5.13)$ & $5.15(5.04 ; 5.22)$ \\
\hline \multirow{4}{*}{$\begin{array}{c}\text { Testicular } \\
13.5 \\
(13.0 ; 14.0)\end{array}$} & \multicolumn{4}{|c|}{ Subgroup 1 (oral administration) } \\
\hline & $13.70(13.50 ; 13.81)$ & $13.11(13.06 ; 13.21)$ & $13.53(13.42 ; 13.60)$ & $13.79(13.66 ; 13.92)$ \\
\hline & \multicolumn{4}{|c|}{ Subgroup 2 (rectal administration) } \\
\hline & $13.57(13.14 ; 13.94)$ & $13.47(13.32 ; 13.55)$ & $13.23(13.04 ; 13.60)$ & $13.27(13.18 ; 13.34)$ \\
\hline
\end{tabular}

Thus, SCS-PEO suppositories, which on the model of turpentine prostatitis showed a distinct prostate protective effect, showed antimicrobial properties against clinically significant agents of inflammation. In terms of toxicodynamics suppositories of the proposed composition can be considered a virtually non-toxic composition, which justifies the feasibility of further study of SCS-PEO as a promising prostate protector.

\section{Discussion of the results}

The absence of statistically significant differences of the studied indicators from the reference ones indicates that the degree of toxicodynamic effect of the combination of active components [32,33] and the excipients [34] of SCS-PEO is consistent with the data reported in the literature. The results of the study on the parameters of acute toxicity indicate that SCS-PEO may be recommended for further preclinical study of specific prostate protective action, as significant toxic effects with single administration at doses exceeding the proposed therapeutic 3-4 times, were not detected. The proposed pharmaceutical composition based on polyethylene oxide based on the parameters of acute toxicity can be attributed to almost non-toxic substances.

Study limitations. The presence of antimicrobial activity in SCS-PEO suggests that there is both an additional therapeutic benefit (inhibitory effect on infectious prostatitis pathogens), and be a potential source of side effects (development of intestinal dysbiosis). The presence of meloxicam in suppositories does not significantly affect the antibacterial effect, but significantly reduces the antifungal activity of the pharmaceutical composition.

Prospects for further research. Given the potential risks of prolonged use, there is a need to consider further studies of SCS-PEO with the long-term introduction of cumulative toxic properties and adverse effects on the intestinal biotope.

\section{Conclusions}

The results show that suppositories with indole-3-carbinol and meloxicam meet the expected toxicity parameters.

SCS-PEO suppositories exhibit a pronounced antibacterial effect against gram-positive and gram-negative bacteria and antifungal action. The revealed features of antimicrobial action make it possible to recommend the use of SCS-PEO for the treatment of not only aseptic but also bacterial (infectious) forms of prostatitis. 
Suppositories of the combination composition with indole-3-carbinol and meloxicam on a polyethylene oxide basis are a relatively safe preparation and may be recommended for further study of the specific pharmacological action.

\section{Conflict of interests}

No conflict of interest.

\section{References}

[1] Bradlow, H. L. (2008). Indole-3-carbinol as a chemoprotective agent in breast and prostate cancer. In vivo, 22 (4), $441-445$.

[2] Nachshon-Kedmi, M., Yannai, S., Haj, A., Fares, F. A. (2003). Indole-3-carbinol and 3,3'-diindolylmethane induce apoptosis in human prostate cancer cells. Food and Chemical Toxicology, 41 (6), 745-752. doi: http://doi.org/10.1016/s0278-6915(03) 00004-8

[3] Chinni, S. R., Li, Y., Upadhyay, S., Koppolu, P. K., Sarkar, F. H. (2001). Indole-3-carbinol (I3C) induced cell growth inhibition, G1 cell cycle arrest and apoptosis in prostate cancer cells. Oncogene, 20 (23), 2927-2936. doi: http://doi.org/10.1038/ sj.onc. 1204365

[4] Chinni, S. R., Sarkar, F. H. (2002). Akt inactivation is a key event in indole-3-carbinol-induced apoptosis in PC-3 cells. Clinical cancer research, 8 (4), 1228-1236.

[5] Hsu, J. C., Zhang, J., Dev, A., Wing, A., Bjeldanes, L. F., Firestone, G. L. (2005). Indole-3-carbinol inhibition of androgen receptor expression and downregulation of androgen responsiveness in human prostate cancer cells. Carcinogenesis, 26 (11), 1896-1904. doi: http://doi.org/10.1093/carcin/bgi155

[6] Reddy, G. P. V., Barrack, E. R., Dou, Q. P., Menon, M., Pelley, R., Sarkar, F. H., Sheng, S. (2006). Regulatory processes affecting androgen receptor expression, stability, and function: Potential targets to treat hormone-refractory prostate cancer. Journal of Cellular Biochemistry, 98 (6), 1408-1423. doi: http://doi.org/10.1002/jcb.20927

[7] Sung, W. S., Lee, D. G. (2007). In Vitro Antimicrobial Activity and the Mode of Action of Indole-3-Carbinol against Human Pathogenic Microorganisms. Biological \& Pharmaceutical Bulletin, 30 (10), 1865-1869. doi: http://doi.org/10.1248/bpb.30.1865

[8] Ishiguro, H., Kawahara, T. (2014). Nonsteroidal Anti-Inflammatory Drugs and Prostatic Diseases. BioMed Research International, 2014, 1-6. doi: http://doi.org/10.1155/2014/436123

[9] Canale, D., Scaricabarozzi, I., Giorgi, P., Turchi, P., Ducci, M., Menchini-Fabris, G. F. (2009). Use of a novel non-steroidal anti-inflammatory drug, nimesulide, in the treatment of abacterial prostatovesiculitis. Andrologia, 25 (3), 163-166. doi: http:// doi.org/10.1111/j.1439-0272.1993.tb02701.x

[10] Wang, W., Bergh, A., Damber, J.-E. (2004). Chronic inflammation in benign prostate hyperplasia is associated with focal upregulation of cyclooxygenase-2, Bcl-2, and cell proliferation in the glandular epithelium. The Prostate, 61 (1), 60-72. doi: http://doi.org/10.1002/pros.20061

[11] Disilverio, F., Bosman, C., Salvatori, M., Albanesi, L., Proiettipannunzi, L., Ciccariello, M. et. al. (2005). Combination Therapy with Rofecoxib and Finasteride in the Treatment of Men with Lower Urinary Tract Symptoms (LUTS) and Benign Prostatic Hyperplasia (BPH). European Urology, 47 (1), 72-79. doi: http://doi.org/10.1016/j.eururo.2004.08.024

[12] Minnery, C. H., Getzenberg, R. H. (2005). benign prostatic hyperplasia cell line viability and modulation of jm-27 by doxazosin and ibuprofen. Journal of Urology, 174 (1), 375-379. doi: http://doi.org/10.1097/01.ju.0000161598.24740.34

[13] Bombardier, C., Laine, L., Reicin, A., Shapiro, D., Burgos-Vargas, R., Davis, B. et. al. (2000). Comparison of Upper Gastrointestinal Toxicity of Rofecoxib and Naproxen in Patients with Rheumatoid Arthritis. New England Journal of Medicine, 343 (21), 1520-1528. doi: http://doi.org/10.1056/nejm200011233432103

[14] Boehringer Ingelheim Pharmaceuticals. Mobic (meloxicam) tablets prescribing information (2006). Ridgefield, 10.

[15] Choi, C. H., Moon, Y. S., Han, J. H., Lee, K. I., Kim, H. J. (2015). Pat. No. 14/414,883 USA. Composition comprising dendropanax morbiferaextract or compound derived therefrom as active ingredient for preventing and treating benign prostatic hyperplasia.

[16] Carrabba, M., Paresce, E., Angelini, M., Galanti, A., Marini, M. G., Cigarini, P. (1995). A comparison of the local tolerability, safety and efficacy of meloxicam and piroxicam suppositories in patients with osteoarthritis: a single-blind, randomized, multicentre study. Current Medical Research and Opinion, 13 (6), 343-355. doi: http://doi.org/10.1185/03007999509110494

[17] Ravshanov, T. B., Zaychenko, G. V., Zaychenko, V. S., Ruban, O. A. (2018). Farmakologichne doslidzhennya supozitoriiv dlya likuvannya dobroyakisnih zahvoryuvan peredmihurovoi zalozi. Web of Scholar, 1 (8 (26)), 51-57.

[18] Stefanov, O. V. (2001). Doklinichni doslidzhennya likarskih zasobiv. Kiiv: Avicena, 292-306.

[19] Pharmacopoeia B. (2016). British pharmacopoeia.

[20] European Pharmacopoeia Commission. European pharmacopoeia. Vol. 2. Maisonneuve. 
[21] U. S. Pharmacopeia. National Formulary USP 38 - NF 33. Rockville: The United States Pharmacopeial Convention. Available at: https://www.uspnf.com/official-text/proposal-statuscommentary/usp-38-nf-33

[22] Volianskyi, Yu. L., Hrytsenko, I. S., Shyrobokov, V. P. (2004). Vyvchennia spetsyfichnoi aktyvnosti protymikrobnykh likarskykh zasobiv. Kyiv: Zdorovia, 38.

[23] Khabriev, R. U., Verstakova, O. L., Arzamascev, E. V., Babaian, E. A., Belousov, Iu. B. et. al. (2005). Rukovodstvo po eksperimentalnomu (doklinicheskomu) izucheniiu novykh farmakologicheskikh veschestv. Otkrytoe akcionernoe obschestvo Izdatelstvo Medicina, 832.

[24] Dacenko, B. M., Biriukova, S. V., Tamm, T. I. (1989). Metodicheskie rekomendacii po eksperimentalnomu (doklinicheskomu) izucheniiu lekarstvennykh preparatov dlia mestnogo lecheniia gnoinykh ran. Moscow, 45.

[25] Semina, N. A., Sidorenko, S. V., Rezvan, S. P., Grudinina, S. A., Strachunskii, L. S. et. al. (2004). Opredelenie chuvstvitelnosti mikroorganizmov k antibakterialnym preparatam. MUK 4.2.1890-04. Moscow: Federalnii Centr Gossanepidnazora Minzdrava Rossii, 91.

[26] Yevropeiska konventsiia pro zakhyst khrebetnykh tvaryn vid 1986 r. Available at: http://zakon5.rada.gov.ua/laws/show/994_137

[27] Pro zakhyst tvaryn vid zhorstokoho povodzhennia (2006). Zakon Ukrainy No. 3447-IV. 21.02.2006. Vidomosti Verkhovnoi Rady Ukrainy, 27, 230.

[28] Larianovska, Yu. B., Kotelevets, N. V. (2005). Morfostruktura peredmikhurovoi zalozy bilykh laboratornykh shchuriv. Medytsyna sehodnia y zavtra, 1, 12-14.

[29] Glanc, S. (1999). Mediko-biologicheskaia statistika. Moscow: Praktika, 459.

[30] Fiziologicheskie, biokhimicheskie i biometricheskie pokazateli normy eksperimentalnykh zhivotnykh (2013). Saint Petersburg: Izd-vo «LEMA», 116.

[31] Meloksykam. Informatsiinyi fond «Derzhavnyi reiestr likarskykh zasobiv Ukrainy». MOZ Ukrainy. Available at: http://drlz. com.ua/

[32] Shertzer, H. G., Sainsbury, M. (1991). Intrinsic acute toxicity and hepatic enzyme inducing properties of the chemoprotectants indole-3-carbinol and 5,10-dihydroindeno[1,2-b]indole in mice. Food and Chemical Toxicology, 29 (4), 237-242. doi: http:// doi.org/10.1016/0278-6915(91)90020-8

[33] Lehmann, H. A., Baumeister, M., Lützen, L., Wiegleb, J. (1996). Meloxicam: A toxicology overview. Inflammopharmacology, 4 (2), 105-123. doi: http://doi.org/10.1007/bf02735465

[34] Nathan, A., Zalipsky, S., Ertel, S. I., Agathos, S. N., Yarmush, M. L., Kohn, J. (1993). Copolymers of lysine and polyethylene glycol: a new family of functionalized drug carriers. Bioconjugate Chemistry, 4 (1), 54-62. doi: http://doi.org/10.1021/ bc00019a008 